\section{Compare and contrast Grameen Shikka (Education) and Bangladesh Rural Advancement Committee (BRAC) education in Bangladesh}

\author{
Rouf, Kazi Abdur $\measuredangle$ \\ University of Toronto, Canada \\ Noble International University, USA (rouf56@yahoo.ca)
}

Received: 15 September 2013 Available Online: 20 November 2013

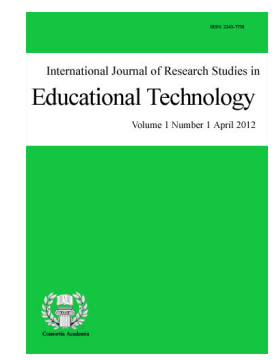

ISSN: $2243-7738$ Online ISSN: 2243-7746

OPEN ACCESS

\title{
Abstract
}

Grameen Shakki child education services and BRAC education programs in Bangladesh are well known for NGOs managed community child education in the world. Their programs are targeted to poor children and they are inclusive to community partners in Bangladesh although their child education programs are in experimental stages. BRAC education program is widely circulated in the world and many agencies want to replicate its model to different countries. This research is author's personal what programs and strategies these two organizations are using that are different from Bangladesh publicly and privately managed children schools. This research attempted to know what are their programs, how they are working and managing child education, their cost-effectiveness of the programs in Bangladesh. The author reviewed literatures related to child inclusive education, uses secondary sources of information about these two organizations and their web texts. In addition, the author also uses his personal experience working in Bangladesh. The study indicates that BRAC-BEP program and GS child education services are inclusive to poor children in Bangladesh. Their programs are popular in their operating areas. Although public child education system is free in Bangladesh; however, these two agencies schools and their child learning centers have huge demand in Bangladesh. Throughout this study, the author realizes that it needs a nation-wide study to compare and contrast performances and the effectiveness of the systems of the publicly managed child education and NGOs managed child education, and privately managed child education in Bangladesh.

Keywords: BRAC education program; Community learning centers; Grameen Bank Center Schools; Grameen Shikka; NGOs managed child education 


\section{Compare and contrast Grameen Shikka (Education) and Bangladesh Rural Advancement Committee (BRAC) education in Bangladesh}

\section{Introduction}

Bangladesh has a high drop-out rate in both primary and high schools. Primary enrolment rate is $86 \%$; so $14 \%$ children never attend school. About a half of the primary entrants drop out before completion of grade five. Nearly half of the primary graduates did not enroll in high school. Total Net Intake Rate (NIR) 91\% (UNICEF, 2005). Total Youth Literacy Rate (15-24 years) is 64\%, (1995-2004). Total Adult Literacy Rate (15 years and over, 1995-2004) is $47 \%$. Adult male literacy rate is $54 \%$ and adult female literacy rate is $41 \%$ (Source: UNICEF Bangladesh, 2005). Grameen Shikka (GS) and Bangladesh Rural Advancement Committee Education Program (BRAC-BEP) attempted to fill up the gap of child illiteracy. GS also tries to fill up deficiencies of youth vocational skills through its vocational training services to unemployed youths in Bangladesh.

\subsection{Objectives of the Research}

Grameen Shikka and BRAC are two national level NGOs in Bangladesh. The author intended to research on NGOs managed community child education in Bangladesh managed by Grammen Shikka education services and BRAC education program. This study could assist Grameen Shikka and BRAC-BEP and other educational agencies in Bangladesh to share their (GS and BRAC-BEP) services and implementation strategies that they are using. The research report could assist other NGOs too to get information and ideas about these two organizations.

\subsection{Research Questions}

$>\quad$ What are the educational services provided by GS and BRAC? How are they are operated?

$>$ What are the benefits that children and youths get from GS and BRAC education program?

Dow many GS/BRAC graduates graduated at different levels? How many of them get employment or get involved in business?

> Do GS and BRAC graduated scholars encourage and coach neighboring poor children for schooling and studying;

$>$ What are the perceptions of GS and BRAC scholarship recipients regarding child marriage, dowry, and women's autonomy in the family?

$>$ Do GS and BRAC run their programs as revenue generating social enterprise? If so, how they generate revenues? How could they manage their programs if donations discontinue or reach selfsufficiency? What are their future expansion plans/services of GS and BRAC?

\subsection{Methodology}

Collect and study Bangladesh NGO's non-formal education program materials, particularly BRAC, BEP and GS. Analyze their texts. The researcher was unable to talk with BEP and GS executives over Skype in order to understand their non-formal education systems, services, strategies and monitoring devices in Bangladesh.

\subsection{Background of Grameen Shikka and BRAC Education Program}

Grameen Shikka (Education) is a Grameen family organization that was established in 1997. It formally 
started education programs in Bangladesh although Grameen Bank (GB) Center School informally first initiated by the author (Kazi Abdur Rouf) in 1981. Before Grameen Shikka (GS), Grameen Bank Center Schools were very popular in Bangladesh during 1981-1988.

Grameen Skikka spreads its education services to poor children and poor people in Bangladesh in order to create illiteracy-free and-poverty-free society by providing educational services to poor children and financial support to poor meritorious students in the form of scholarships. GS is working for to promote mass education through formal and non-formal methods; to organize and facilitates pre-school child education and adolescents girls, boys and adult people; to promote new and appropriate educational technologies- satellite Internet, distance learning methods etc. as well as innovate ideas and methods for child education with a view to alleviating illiteracy; and to conduct research and undertake experiments in education. Its vision is to spread education to poor children and people in order to create illiteracy free society and poverty. On the other hand, BRAC-BEP endeavor is to provide child educational services to poor children in Bangladesh. With this aim, BRAC-BEP organizes and facilitates non-formal primary level education for poor children in Bangladesh. It has agenda to improve access to education to poor children. Their (GS and BRAC-BEP) main objectives are to promote child education in outreach rural areas. However, GS has additional services to provide information technology support to poor students and unemployed youths, and conduct educational research in the field of education.

Grameen Shikka is registered with the Office of the Registrar, Joint Stock Companies as well as with the NGO Affairs Bureau. Its main objectives are to promote mass education in rural areas, organize facilities for education and training, provide financial support in the form of loans and grants for the purpose of education, use information technology to bring an end to illiteracy, and development of education, promote new technologies and innovate ideas and methods for development of education, and conduct research and undertake experimentation in the field of education.

Grameen Shikka is extension of Grameen Bank's efforts to address one of the basic needs of the rural poor-education-to help them break away from the shackles of poverty. It is part of the Grameen Bank's multidimensional agenda, built around its core micro-credit program, to focus on poverty alleviation. Grameen Shikka creates awareness on diverse issues like health, human rights, gender equity etc among the rural poor and their children through formal and informal methods.

Since 1997, Grameen Education has included 'Pre-school Program', 'Early Childhood Development Program', 'Non-formal Education for Slum Children', 'Vocational Training Program', and 'Life Oriented Education Program' in 64 districts of Bangladesh to educate youth through formal and informal education (Grameen Shikka, 2013). Moreover it has Arsenic Mitigation Program and Vocational Training Program in different districts of Bangladesh.

\subsection{Attachment to Grameen Center Schools and the background of Grameen Bank Center Schools (1981-1988)}

The author first informally initiated the Grameen Bank (GB) Luhuria Center School in 1981, when he was working with Grameen Bank Narandia Tangil branch in Bangladesh in 1981. In collaboration with GB and other field staff, he causally started literacy and numeracy basic learning for children in Luhuria village after office hours. Parents encouraged children to come to this center school. There were 56 children in this center school. The center school provided education coaching services to poor children with love and care. Children did physical exercises, chorus songs, arts, traditional games and other fun activities. Children enjoyed those activities very much. This message spread to other neighboring centers. Other customers of the branch asked the bank manager to start a center school in their areas. In 1981, the Narandia Tangil branch informally assisted to run 36 center schools in 1981-1983. The aim of GB center schools was to develop schooling behavior among marginalized children, make them ready for schooling stage, and coach poor children to learn literacy, numeracy and basic religious education. Center school activities had increasing impact on elementary school enrollments, class performances, and happiness among these children. 
In 1982, author was posted to GB Dhaka head office and was assigned to manage the special programs of the bank, such as managing women workshops, borrowers' exchanging visit, center school programs, child welfare programs, seed vegetables distribution and fruits/timber samplings distribution programs. With the help of UNICEF Bangladesh, the author collected 10,000 literacy books and 10,000 numeracy books. He distributed these books for free to five zones of GB branches in 1982. The GB center schools were voluntarily managed, but they were very popular in the community. Each school contained on average 50 children of different grades from preschool to grade 6. In 1984-1988, GB center schools numbers reached 400,000 across Bangladesh. All GB center schools were managed by the borrowers themselves.

GB management aware of child education demands. Grammen Shikka become an independent body deals with education programs like collecting funds for children education, managing funds, organizing GB schools, supply educational logistics to children, provide stipends and scholarships to students. Side by side GB introduced education loans to GB borrowers' children for continuing their education. GS initiated child education program near Dhaka and Tangail in a limited scale financed by Save the Children Fund USA in 1997. GS experiment some of child education ideas, but GB schools are not parallel like Government elementary schools. The author was assigned to draft student education loans manual for GB borrowers' children in 1997. Then GB started education loan to borrowers' children since 1997.

\subsection{Why GB Center School discontinue}

Grameen Bank main program is micro-credit. As GB did not have a budget for center schools, GB could not supply logistics to the center schools. GB increased multiple loan products that loaded field staff with loan transactions. The GB center schools had ran and had managed by GB without funding from GB or other sources. Without resources, it was difficult for GB field offices to continue the GB schooling program. Hence GB center schools didn't incubate continuously because of constrained funding. However, GB field staff encouraged guardians to save money regularly and pay center schools' teachers and those who teach in schools. According to this model, many center schools were managed by GB borrowers themselves. However, child education slogans/ campaigns were continued by GB through GB sixteen decisions.

By September 15, 2011 Grameen Shikka (GS) has supported more than 3200 poor students with scholarships. GS has provided pre-school education to more than 100,000 children in Bangladesh. GS started its vocational training program in early 2008 (Grameen Shikka, 2013). AS of January 2013, it provides 2000 youths with vocational training. Its vocational training courses are training in tailoring and dressmaking to poor adolescent girls and women in Chilmari, solar installation technician training, industrial sewing, garment machine mechanics, electrical and electronic control, electronics and telecommunications, computer fundamentals and applications, mobile phone repairing, solar home system management etc. (Ibid, 2013). GS has satellite training centers too. GS provides scholarships to poor trainees. These scholarships cover $50-80 \%$ of the total course fees, but those who are totally unable to pay fees, were provided by GS with full scholarships. Training fees range from (\$7-\$25) depending on the trade courses. GS set up a manpower company, called Grameen Employment Services Ltd. (GESL), to train employed young people interested to work abroad and assist them to find jobs overseas.

\section{Literature Review}

Young children's development does not occur in isolation; rather it takes place in a rich context of direct and indirect influences (Bronfenbrenner, 1979). The author believes that children and their education programs should be linked with comprehensive family services and community services especially to disadvantaged children although it is expensive and time consuming, but it could be more effective. For example, child education program need to be directly connected with child welfare, parenting services, nutrition and health services and other child poverty eradication programs. 
GS has parenting care giving program. Under this program, GS assists parents/caregivers to increase their knowledge, skill and confidence for overall development of their children aged 0-3. Particular developmental needs of the target children include various motor, cognitive, languages, social and emotional needs. Grameen Shikka has provided parenting training to more than 135 thousand parents/caregivers in different districts of Bangladesh (Grameen Shikka, 2013). This program assists caregivers to increase their knowledge, skills and confidence for overall development of children aged 0-3. Non-formal education for slum children is also essential in Bangladesh. Grameen Shikka is running 20 non-formal slum schools (one-room school) in slum areas in Dhaka City. Here are 600 students in these schools (Grameen Shikka, 2013). 30 students are in each school. These non-formal schools are providing education up to grade 5. Students receive lesions in local Bengali, simple English, and math, environment and social responsibilities etc. Government curriculum books are used in these schools. Non- Formal Education for Slum Children is undertaken to provide basic education competencies to slum children. This program is financially supported by Children in Slum and Development (CISD).

Weigel and Martin (2006) in their paper 'Identifying Key Early Literacy and School Readiness Issues: Exploring a Strategy for Assessing Community Needs, mentions the above the perceived assets need to be available to address early literacy and school readiness issues in his diagram. This holistic mapping allowed us to target and involve a wide variety of professionals involved in early childhood issues from a broad geographic area, many of whom would not have been able to travel to a central location on a regular basis (Morrow, 1995; Walker et al., 1996). This process could ensure that everyone's voice and ideas included for the disadvantaged child justice education. This mapping also provides vital information to those designing and delivering child educational intervention programs. Such a technique allows for the potential agencies to better target programs than otherwise might have occurred had programs been implemented without such information. Children acquire skills and knowledge in a variety of formal and informal settings, including the home, child care programs and other community settings (Bryant et al., 1994; Dickinson \& Smith, 1994; Kuby \& Aldridge, 2004).

Despite the variety of programs that have been developed by GS and BRAC-BEP in Bangladesh, not all programs are available in each community. There are still many poor children and families who have not had access to programs that fit their needs. Before offering new or additional programs, educators and service providers would be best served by assessing the needs of their local community (Dickinson, 1994); Morrow, 1995; Murphy and Burns, 2002; Weigel \& Martin, 2006). Needs assessment is the term used to describe efforts at collecting information to guide program and service delivery efforts, and it is the first step in Murphy and Burns, 2002; Weigel \& Martin, 2006); comprehensive model of planning and evaluation of family service programs. Reviere, Berkowitz, Carter, and Ferguson (1996) define needs assessment as "a systematic and ongoing process of providing usable and useful information about the needs of the target population- to those who can and will utilize it to make judgments about policy and programs" (p. 6).

\section{Outputs and Outcomes of the GS Education Program}

\subsection{Grameen Shikka Programs, Outputs and Outcomes}

Children, families, schools, and local communalities need to be ready for schooling their children and to accommodate the diverse needs and experiences of children and their families (Walker et al., 1994). Schools teaching (outcomes) to children depend on children, their families attention and the community support services. Therefore, with these in mind although GS and BRAC-BEP has developed their program, however it is not enough. However, these two NGOs are working with poor children. They have included some financial services to meritorious and needy students. An important component of Grameen Shikka's literacy program is Scholarship Management Program. Under this program financial support in the form of scholarship is provided to poor meritorious students to enable them to continue their studies. For example, GS scholarships are assisting 3,600 poor meritorious students to carry on their studies. 
Although richly endowed with talents, these poor boys and girls endure extreme hardships to continue their education. Some live in squalid conditions crammed in small houses; they do not get three meals a day. Many cannot buy text books and stationery. Some houses do not have electricity; they cannot buy fuel for lamps. These unfortunate children perforce finish their studies in day light. They cherish big dreams to become doctors, engineers, computer scientists and many others, but find themselves at odds end to fulfill these dreams.

In 2011 Secondary School Certificate (SSC) finals 121 students got A+, 115 got A, 58 got A-, and 34 got B. Many GS scholars, who started to receive scholarships when they were in high schools, are now studying business, engineering, medicine, literature and social sciences in colleges and universities. Many of them are certainly going to emerge as leaders in the near future. GS has been conducting a non-formal basic education program in 20 schools with a total of 600 students in slum areas of Dhaka City. There are 13, 000 children who are serving under physical and intellectual development program. GS has 500 child development centers with more than 7,000 students in 2010. Grameen Shikkha has provided parenting training to more than 135 thousand parents/caregivers in Bangladesh (Grameen Shikka, 2013). This program assists caregivers to increase their knowledge, skills and confidence for overall development of children aged 0-3. In collaboration with UNICEF and Bangladesh Shishu Academy, GS has trained more than 2,500 Grameen Bank officials, local government leaders and officials, school teachers, religious leaders etc.; more than 4,000 Grameen Bank center leaders; and nearly 135,000 Grameen Bank borrowers on parenting skills (Grameen Shikka, 2013). GS Life Oriented Education Program (LOEP) is an integrated non-formal functional education program for poor rural adolescent girls and women to improve their literacy and numeracy skills, life oriented skills related to health, legal matters, child development, civic consciousness, social services, income generation, business professional development, etc. This LOEP was closed in 2004 due to fund constraint.

Many international donors are funding to Grameen Shikka to run GS education programs. Funders are the Hunter Foundation UK, A. L. Jameel of Saudi Arabia, Vidar Jorgensen USA, the Green Children Corporation USA, Grameen Foundation USA, NOKIA, Rotary International District 2670, Japan, Her Majesty Queen Sofia, Spain, Citi Foundation, and the Shirin Merali Foundation, USA.

\subsection{Grameen Student Loan Program}

As mentioned earlier, Grameen Student Loan Program started in 1997. Author was assigned to draft the student loan manual for GB borrowers' children in 1997. As of February 2013, GB provided \$34.27million of student loans to 51,814 students (male 39,817, female 11,997) for university education, medicine and engineering education and study abroad (Grameen Bank Annual Report 2012).

\section{Table 1}

GS Vocational Training Graduates - as of September 2011

\begin{tabular}{lccc}
\hline Descriptions & Boys & Girls & Total \\
\hline Electrical \& electronic control & 100 & 0 & 100 \\
Elec. House wiring/fan motor rewinding & 47 & 0 & 47 \\
Electronics & 87 & 2 & 89 \\
Industrial sewing & 81 & 98 & 179 \\
Dress making \& tailoring & 17 & 147 & 164 \\
Solar & 154 & 0 & 154 \\
Mobile phone servicing & 164 & 0 & 164 \\
Garment machine mechanics & 85 & 0 & 85 \\
Computer applications \& Internet & 347 & 192 & 539 \\
Computer hardware & 7 & 0 & 7 \\
Graphics & 5 & 3 & 8 \\
Total & $\mathbf{1 , 0 9 4}$ & $\mathbf{4 4 2}$ & $\mathbf{1 , 5 3 6}$ \\
\hline
\end{tabular}

Source: Grameen Shikka Annual Report 2012. 


\section{Bangladesh Rural Advancement Committee (BRAC)}

The Bangladesh Rural Advancement Committee (BRAC) initially focused on assisting refugees returning from India to their newly independent country at its earlier stage.

\subsection{BRAC Education Program (BEP)}

The Bangladesh Rural Advancement Committee (BRAC) is a non-governmental development organization that was founded in early 1972. It initially focused on assisting refugees returning from India to their newly independent country. BRAC main program is non-formal primary level education for poor children in Bangladesh is well marketed all over the world although Grameen center school child non-formal education innovations had run 1980-1988 massively across Bangladesh. BRAC education program objectives are to provide quality primary education for children outside formal education institutions; to improve access to education, especially for girls and to enhance the success of formal primary education through pre-primary schools.

BRAC education program has formally named in 2003 that carries out its program in five major areas: (1) Non-formal Primary Education for underprivileged children; (2) the Pre-primary Schools program; (3) The Adolescent Development Program (ADP); (4) The Multi-purpose Community Learning Centers with IT facilities; and (5) 'The Mainstream Secondary Schools Support' building the capacities of rural secondary school teachers for improving classroom pedagogy. BRAC continued its education throughout years by receiving resources from abroad (BRAC-BEP, 2013).

BRAC initiated the BRAC Education Program-BEP in 1985 in an effort to address some of these challenges. In 2003 it was renamed as BRAC Education Program (BEP). School premises are rented from the community, but GB center schools run in GB center house in free. BRAC's educational activities started in 1985 with just 22 one-room schools. The activities covered three upazillas, served less than 700 children administered by five paid staff (BRAC-BEP-2013).

BRAC also has Adolescent Centres where adolescents are given a residential Training of Trainers (TOT) which enables them to facilitate the adolescents courses themselves. Moreover, BRAC has 'Multi-Purpose Community Learning Centres'. BRAC Multi-Purpose Community Learning Centres are mostly run by local women selected by the BRAC Program Organizers (POs). BRAC employs one facilitator per school/centre, except for multilingual schools, which have two facilitators. The average number of learners per facilitator ranges from 25 to 33 (BRAC, 2013).

\subsection{BRAC Funding Sources}

According to the 2007 audit report of BRAC, the annual cost (January to December) of the Education program of BRAC is BDT 3,322,331,606 (equivalent to USD 47,461,880 according to current conversion rates). The average cost per learner is USD 23 per year. BRAC BEP program is donor-supported. BRAC funders to BRAC education program (BEP) are DFID, CIDA, Royal Netherlands Embassy, Royal Norwegian Embassy, Oxfam, NOVIB, UNICEF and Aus-Aid.

\subsection{Primary comparison between BRAC and GS child education programs, and vocational education programs}

BRAC education and Grameen Shikka education programs' target mainly: children aged 5+ who eligible for pre-primary schooling; out-of-school children (8-10 and 11-14 years), with a special focus on girls; youth (15-24 years); poor populations and the unemployed; and children with special needs (children from poor urban slums, remote rural/hard-to-reach areas, children with disabilities). They also provide family literacy; environmental education; and female gender preference with individual care and attention. The average number of learners per facilitator ranges 25 to 33 . BRAC school premises were rented out by the community, but GB center schools 
were not rented. BEP has reached 470 of the 482 upzillas in all 64 districts of Bangladesh (BRAC, 2013). GS has vocational training program for unemployed youths that service is not available in BEP. According to BRAC (2013) almost 1.1 million children participate in BRAC schools each year. 3.8 million Children have graduated and 2.3 million children have successfully completed the pre-primary school (BRAC-BEP, 2013).

Both organizations deal with basic literacy skills, basic numeracy skills and life skills. Both have strategies for community and parental involvement in the schools. They have the School Management Committee (SMC) for each school management. Both agencies believe community active participations are important for effectiveness of the education programs. However, effective monitoring and evaluation processes are crucial for the ongoing enhancement of the program. BRAC-BEP education focuses on social issues: child rights, child marriage, gender, dowries, sexual abuse, substance abuse, child trafficking, domestic violence, acid throwing, divorce, terrorism, etc.; health issues: reproductive health, STIs, HIV/AIDS, family planning, personal hygiene, etc. and life skills: decision-making, negotiations, effective communication, problem-solving, critical and creative thinking, etc. GS could include these tips in its lesson planning and learning. GS has started trade courses, technical skills training for the rural unemployed youths that are very effective to get employment in Bangladesh. BRAC could include trade courses and technical skills trainings to rural unemployed youths in Bangladesh.

\section{Conclusion}

Now it is an age of information technology (IT), but it is expensive for disadvantaged people in Bangladesh. The IT knowledge and facilities available to them could help them searching for job markets, access to information on e-businesses and e-markets, e-health, e-nutrition and many other e-news. Moreover, these marginalized people could engage in virtual networking with other people through web networking. Hence availabilities of IT resources, access to Internet facilities and availability of computer training for them can benefit them to learn and to develop their skills on how to use information technology like use computers, repairs computers and use Internets etc. Hence Grameen Shikka and BRAC could provide IT facilities and provide training to disadvantaged people in Bangladesh so that they could develop and apply IT knowledge and skills in their life. Therefore, these community organizations could built-in IT training programs and IT resources available to them so that these people could get benefit from IT resources and IT trainings across Bangladesh.

Although GB field staffs encourage child education, campaign for education and motivate borrowers running center schools by themselves, but GB field workers were overloaded with GB loan services. However, GS staff and GB staff could collaborate each other to promote and implement massive child literacy program in Bangladesh. Although BRAC education program objectives are to provide quality primary education for children outside formal education institutions; to improve access to education, especially for girls and to enhance the success of formal primary education through pre-primary schools; however, it could also focus on child poverty and parental literacy issues. Moreover, they could include parent workshops or home-visitor programs in their programs. This could help NGOs know more about the children and their family issues (Kuby \& Aldridge, 2004). The researcher personally gains valuable experience from the study that might assist him to develop his future professional career in NGOs managed education programs.

\section{References}

BRAC. (2013a). BRAC pre-primary School. Retrieved August 13, 2013 from http://education.brac.net/pre-primary-schools

BRAC. (2013b). BRAC Home. Retrieved August 13, 2013, from http://education.brac.net/

BRAC. (2013c). BRAC Inclusive Education. Retrieved August 13, 2013, from http://education.brac.net/inclusive-education

BRAC. (2013d). Support to Formal Schooling: Cooperation with Government. Retrieved August 13, 2013, from 
http://education.brac.net/support-to-formal-schooling-cooperation-with-government

BRAC. (2013e). Multi-purpose Community Learning Centres (Gonokendros). Retrieved August 13, 2013, from http://education.brac.net/multi-purpose-community-learning-centres

Bronfenbrenner, U. (1979). The ecology of human development: Experiments by nature and design. Cambridge, MA: Harvard University Press.

Bryant, D. M., Burchinal, M., Lau, L. B., \& Sparling, J. J. (1994). Family and classroom correlates of Head Start children's developmental outcomes. Early Childhood Research Quarterly, 9(3-4), 289-309.

Country Profile Bangladesh (2013). BRAC Education Program. Retrieved August 14, 2013, from http://www.unesco.org/uil/litbase/?menu=4\&programme $=28$

Dickinson, D. K. (Ed.). (1994). Bridges to literacy: Children, families, and schools. Cambridge, MA: Blackwell.

Dickinson, D. K., \& Smith, M. W. (1994). Long-term effects of preschool teachers' book readings on low-income children's vocabulary and story comprehension. Reading Research Quarterly, 29(2), 104-122.

Grameen Bank Annual Report (2012). Grameen Scholarship Program. Grameen Bank. Packages Corporation: Dhaka, Bangladesh.

Grameen Shikka. (2013a). Grameen Shikka introduces industrial electrical wiring training. Retrieved August 12, 2013, from http://www.grameenshikkha.com/

Grameen Shikka. (2013b). Grameen Shikka Scholars Perform Excellent in 2013. Retrieved August 12, 2013, from http://www.grameenshikkha.com/index.php?option=com_content\&task=view\&id=64\&Itemid=94

Grameen Shikka. (2013c). Programs. Retrieved August 10, 2013, http://www.grameenshikkha.com/index.php?option=com_content\&task=blogsection\&id=4\&Itemid=59

Grameen Shikka. (2013d). Projects. Retrieved August 13, 2013, from http://www.grameenshikkha.com/index.php?option=com_content\&task=blogsection\&id=6\&Itemid=91

Morrow, L. M. (1995). Family literacy: Connections in schools and communities. Newark, DE: International Reading Association.

Kuby, P., \& Aldridge, J. (2004). The impact of environmental print instruction on early reading ability. Journal of Instructional Psychology, 31(2), 106-114.

Reviere, R., Berkowitz, S., Carter, C. C., \& Ferguson, C. G. (1996). Needs assessment: A creative and practical guide for social scientists. Washington, DC: Taylor \& Francis.

UNICEF Bangladesh (2005). Bangladesh Profile. UNICEF Bangladesh. Dhaka.

Walker, D., Greenwood, C., Hart, B., \& Carta, J. (1994). Prediction of school outcomes based on early language production and socioeconomic factors. Child Development, 65(2), 606-621. http://dx.doi.org/10.2307/1131404

Weigel, D. J. \& Martin, S. (2006). Identifying Key Early Literacy and School Readiness Issues: Exploring a Strategy for Assessing Community Needs. Early Childhood Research and Practice, 8(2). 
Rouf, K. A. 